\title{
Kjønnssykdom i Tysklandsbrigaden
}

I april 1950 publiserte Tidsskriftet en artikkel som vakte oppmerksomhet. 16. april 2010, 60 år etter, ble den trukket frem igjen i avisenes «på denne dag»-spalte. «58 av 1.000 soldater i den norske Tysklandsbrigaden hadde pådratt seg veneriske sykdommer. Forekomsten av syfilis var sju ganger så stor som blant soldatene hjemme i Norge. 42 prosent av soldatene i siste brigade hadde hatt samleie med tyske kvinner. Sersjantene var den gruppen som hadde mest kjønnssykdommer.» Tallene var hentet fra en artikkel av Tore Berdal (1909-74), som ifølge Norges leger var venerolog i Tysklandsbrigaden i seks måneder i 1949 (Tidsskr Nor Lægeforen 1950; 70: 221-3).

\section{Veneriske sykdommer i de fem første tysklandsbrigader}

I tiden fra februar 1947 til august 1949 har fem norske brigader tjenestgjort som okkupasjonstropper i den britiske sone i Tyskland. De tre første brigader var forlagt i Hannover District, de to siste i brigader i Schlesvig-Holstein. Hver brigade har hatt en gjennomsnittlig styrke på 4400 mann, og i løpet av $2 \frac{1}{2} 2$ år har ca. 22000 mann rekruttert fra alle kanter av landet, gjort tjeneste i Tyskland. [...]

Arsakene til den høye venereafrekvens blant Tysklandssoldatene sammenlignet med Hærens avdelinger hjemme i Norge, må sees på bakgrunn av følgende forhold.

1. Høy venereafrekvens blant den tyske sivilbefolkning. Hyppigheten av kjønnssykdommer i Tyskland under krigen var meget stor, og har etter krigen vist bare ubetydelig tilbakegang.

2. De norske soldater har i stor utstrekning fraternisert med de tyske kvinner. En undersøkelse som en har foretatt blant 2700 soldater i siste brigade viser at ca. $42 \%$ av guttene har hatt coitus under tjenesten i Tyskland, for største delen med tyske kvinner.

3. Soldatene har i for liten utstrekning brukt smitteforebyggende midler (kondom) for å beskytte seg mot kjønnssykdom. Ved en undersøkelse blant soldatene viste det seg at bare ca. $30 \%$ hadde brukt kondom under coitus.

4. Alkohol har uten tvil vært en medvirkende årsak til den høye venereafrekvens. Av 175 pasienter i brigade 491, med syfilis, gonoré og uspesifikke urethritter, hadde 115 pasienter eller $66 \%$, vært påvirket av alkohol under coitus.

5. De norske avdelinger har vært forlagt i utkanten av tyske byer, og det har vært lett for soldatene å søke kontakt med de tyske kvinner. 